\title{
Relationship of Transformational Leadership and Work Motivation Through Discipline and Teacher Performance
}

\author{
Laxni Rezita Sulaxono*, Sulaiman, Ahmad Suriansyah \\ Master Program of Education Management, Universitas Lambung Mangkurat, Banjarmasin 70123, \\ Indonesia
}

Article history:

Submission December 2019

Revised September 2020

Accepted September 2020

*Corresponding author:

E-mail: rezitalaxni@gmail.com

\begin{abstract}
This study aims to analyze the relationship between transformational leadership, work motivation, discipline, and teacher performance. The descriptive method with a corrective technique was used to describe the relationship that exists between two or more variables. A total of 135 teachers and 101 respondents were taken as research samples using the proportionate stratified random sampling technique. Data was collected using a questionnaire that has been valid and reliable and analyzed using Path Analysis. The results showed that: (1) There was a direct relationship between transformational leadership, work motivation, discipline, and teacher performance (2) There was a no indirect relationship between transformational leadership, work motivation, disciplined teacher performance.
\end{abstract}

Keywords: Transformational leadership, work motivation, discipline, teacher performance

\section{Introduction}

Teachers need to possess the right teaching skills to adequately manage the various stages of learning, through media, and proper time allocation. Teaching skills enable teachers to show their professional competencies. When teachers' performance in an educational institution is poor, achieving set objectives becomes difficult. This performance is seen from their success to teach students in and outside the classroom, both directly and indirectly. The performance of a teacher is very influential in the progress of the school and also in the educational process because it refers to their behaviors in carrying out their duties (Supriyadi, 2002). Teachers with good performance scores certainly have an impact on the results of their activities, where the output increases in quality and quantity. The performance of educational institutions in Indonesia is far from adequate (Usman, 2011). Its conditions are inseparable from the role of the teacher as an educator, and a determining factor for the success of the school. This shows that the low quality of education is partly due to the poor performance of teachers.

Therefore, teachers need to strive and maintain high performance. Answers need to be sought to determine the various factors that influence the improvement of teacher performance, especially Primary School Private teachers. The world of education is unable to experience changes due to lecturers and teachers' inability to adapt and anticipate change (Bubu, 2016). Many factors affect the improvement of teacher performance. Teacher performance is influenced by several factors, such as the principal's leadership style, work motivation, and discipline. These factors have a different picture in each region, one of the factors influencing the performance of school teachers, principals' leadership (Supardi, 2014). Principals play the roles of educators, managers, administrators, supervisors,

How to cite:

Sulaxono, L. R. (2020). Relationship of Transformational Leadership and Work Motivation Through Discipline and

Teacher Performance. Journal of K6, Education, and Management, 3 (1), 57 - 65. doi: 10.11594/jk6em.03.01.08 
leaders, innovators, and motivators. Furthermore, a school principal is required to possess a transformational leadership style that rapidly adapts to the environment, with cooperation from the teachers and employees to improve organizational performance (Aslamiah, 2015).

Good transformational leadership needs to be able to strive for the performance of teachers through education staff capacity building programs. Therefore, the principal needs to possess the right personality, abilities, and skills to lead an educational institution. In their role as a leader, they need to be able to pay attention to the needs and feelings of teacher s and students.

Besides, the motivation factor also affects the performance of teachers. Motivation is important because it supports one's behavior to work hard and enthusiastically to achieve optimal results.

The poor motivation of private primary school teachers in the District of North Banjarbaru is due to the lack of efforts to increase knowledge and teaching skills. This includes education, training, and workshops. It is difficult to achieve the growing motivation required to influence teachers' performance to achieve organizational goals. This is due to the different human behaviors and characteristics according to their needs. Furthermore, the differences or gaps in the perceptions of members and leaders regarding perceived and expected motivation, which decreases work, led to abuse of rights and obligations, which ultimately resulted in poor teacher performance (Supardi, 2014).

The next factor that affects performance is discipline. This is defined as the awareness and willingness of a person to obey all applicable organizational rules and social norms (Hasibuan, 2010). High discipline tends to build the professional performance of good teachers, which enables them to examine the rules and make strategic steps in implementing the learning and teaching process to achieve optimal performance. Stated that teacher work discipline is influenced by various internal and external factors, such as motivation, enthusiasm for work, initiatives, level of welfare, leadership style, assertiveness, supervision, and incentives. Many factors affect the performance of teachers, such as the ability to build good communication skills, improving teaching abilities through training, etc (Hasibuan, 2010).

This study aimed to establish how the transformational leadership, work motivation, and discipline influence teachers' performance in primary school private in North Banjarbaru District. Teachers at primary private school at North Banjarbaru District was considered underperformed due to lack of preparedness. In several cases, teaching and learning materials were shared amongst the teaching staff. The findings in the preliminary study above reveal that the performance of teachers in the Hulu Sungai Tengah District High School must still be optimized, including improving the transformational leadership, improving teacher work discipline, and increasing teacher work motivation. This is because these three aspects are the deciding factors on the performance of teachers in primary private schools in the North Banjarbaru District.

\section{Material and Methods}

This research is explanatory research with a quantitative approach and was carried out in August 2019 involving 6 (six) primary private schools in North Banjarbaru District. The number of samples in this study was 101 teachers. Data collected through questionnaires, observation, and documentation. Data were analyzed quantitatively using path analysis with the help of SPSS version 22.

\section{Results and Discussion}

The results of respondents' descriptive statistical analysis of the research variables, namely emotional intelligence, interpersonal communication, job satisfaction, and teacher performance measured on a scale of 5 are shown in Table 1 which includes the mean, standard deviation, and categories. 
Table 1. Mean, Standard deviation, and categories of research variables

\begin{tabular}{lccc}
\hline \multirow{2}{*}{ Variable } & \multicolumn{3}{c}{ Descriptive } \\
\cline { 2 - 4 } & Mean & Standard Deviation & Category \\
\hline Transformational & & & \\
Leadership & 125.3663 & 8.31351 & High \\
Work Motivation & 119.4554 & 8.16520 & High \\
Discipline & 117.1584 & 11.16130 & High \\
Teacher & 36.3960 & 6.31360 & Medium \\
Performance & & & \\
\hline
\end{tabular}

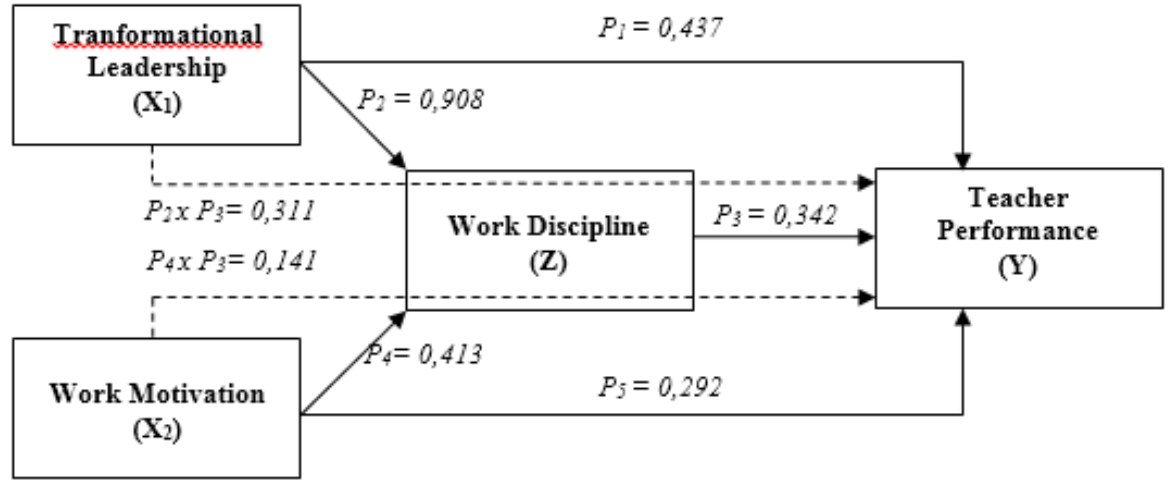

Figure 1. Results of Analysis of the Relationship between Transformational Leadership (X1), Work Motivation (X2), Discipline (Z) and Teacher Performance (Y).

The direct relationship of transformational leadership on the performance of teachers

Based on the hypothesis test results, a significant relationship of leadership variables is seen on the performance of Private Elementary School teachers in the North Banjarbaru District. This is evidenced by several test results, such as the coefficient of regression results of 0.437 , which is interpreted from the performance of each one unit. The is seen on the t-test result with a significant value of $0,000<0.05$ and $7,004>1,984$. Therefore, the relationship of transformational leadership on teacher performance is significant, meaning that the better the leadership, the higher the teacher's performance. Furthermore, the results of the value of $\mathrm{R}^{2}$ (RSquare) or the coefficient of determination of 0.331 mean that $33.1 \%$ changes in teacher performance variables are influenced by leadership. The results of the study are following the answers of leaders, in this case, the principal with transformational leadership ability to influence the performance of teachers. This shows the principal has been able to create working environment conditions that provide stimulation for employees to work optimally. The leadership style is also called a comprehensive pattern that is visible and invisible to the subordinates.

Transformational leadership is based on the influence and relationship of leaders with followers or subordinates (Usman, 2011). They feel trust, admiration, loyalty, and respect for leaders, with a high commitment and motivation to excel. The principal element of transformational leadership is the ability to influence teachers, staff, and other school members. This influence is realized through Bass and Avolio's theory, which stated that transformational leadership has four characteristics, namely inspirational motivation, intellectual stimulation, and individual consideration. Although Bass often adds one more characteristic, and it is an extension of idealized influence, namely charisma (Usman, 2011). The management of a principal's leadership function can influence teacher performance. Therefore, the success of educational goals is easily achieved. 
Principals rated by teachers as having this attitude are known to possess charisma. Charismatic, transformational leadership can provide vision and sense of mission, to inculcate a sense of pride, gain respect and trust (Wahjosumidjo, 2010). Translational leaders are charismatic to their subordinates and possess some power and influence. They are fully respected, possess referent power, therefore, they are worthy of imitation, with high standards, and set challenging goals for their followers.

Based on the results of respondents, it is known that the principal can motivate teachers to become more enthusiastic. This motivation is seen from the attitude of principals that always provide support, encouragement, and inspiration to the ideas of teachers and students., Transformational leadership as the intellectual stimulus of a school principal. This is seen by looking at several indicators, such as the respect of subordinate ideas (promote intelligence), which develops rationality (Rasyidah, 2019). They are the school's public figures and representatives. As well as providing the necessary leadership and direction to teachers to perform as their duties command (Suriansyah 2018).

Transformational leaders encourage teachers to rethink the way their old ways of carrying out activities and thoughts. The principal also always fosters innovation by providing teachers with the freedom to participate in various kinds of training or socialization to support their works. The principal also involves the participation of teachers in solving problems or division of tasks and positions, without being authoritative. The last traditional national leadership function in this study is individual consideration. The principal is known for providing personal attention, respect for individual differences, issuing advice, and direction. Overall, transformational leadership has a close relationship with teacher performance because the success of a leader in motivating others to achieve goals that have been determined is dependent on authority, and motivates teachers. The transformational leadership style is more flexible, therefore, it increases employee creativity and autonomy.
From the transactional relationship, the better the leadership applied by superiors, the better the employee's performance.

\section{The direct relationship of transformational leadership on work discipline}

Based on the results of the second hypothesis test, it was seen that there was a significant influence of leadership variables on the discipline of private school teachers in the North Banjarbaru District. This was evidenced by several test results, such as the value of the coefficient of regression results that is 0,908 , which shows a positive value has an increase of 0,908 per increase in one-unit of the transformational leadership variable. From the results of the ttest, it is seen that the significant value of 0,000 $<0.05$ and 9,134> 1,984, is obtained, which shows the positive influence of transformational leadership on teacher discipline. Furthermore, the $\mathrm{n}$ values of $\mathrm{R}^{2}$ (RSquare) or the coefficient of determination is 0,457 (45.7\%), which means a change in the variable teacher discipline can be affected by variables of transformational leadership.

Discipline is always closely related to the rules and norms applied in the school environment. The application of discipline in a company is one of the most difficult personal problems facing a leadership. Transformational leadership is one of the important factors to determine the behavior of individuals and groups in organizations (Prijodarminto, 2014). The failure in determining leadership style has an impact on the decrease in work discipline. Based on the results of the data obtained from schools, when the teacher discipline level is high, the number of latecomers and those that leave early is limited. This indicates that the leadership style applied is appropriate to minimize the level of violation in terms of discipline. In this case, the influence of transformational leadership is felt by the teachers.

Based on the results of respondents, it is known that the principal can motivate teachers to be more enthusiastic. This motivation is seen from the principal's attitude by providing support and encouragement to the ideas of teachers, and inspiring employees, as well as students. The leadership in this study was also 
seen from the intellectual stimulus of a school principal. This is determined by looking at several indicators. For instance, the principal needs to be a role model for teachers in terms of discipline related to time, attendance and carrying out learning in the classroom. The leader's role is very instrumental in determining employee discipline because they are the role model for their subordinates. Leaders need to set good examples by being disciplined and honest, following the words of the deed. When a leader shows good leadership qualities, the discipline of subordinates is also good (Hasibuan, 2010).

The transformational leadership factor plays an important role in improving teacher discipline due to its effective result in increasing teacher discipline through regulations (Sundari, 2019). Transformational leadership is instrumental in determining teacher discipline as they act as role models to their subordinates (Wahjosumidjo, 2010). Leaders do not need to expect the discipline of their subordinates to be good when theirs is bad. Several factors influence employee work discipline, such as the actions of a leader as a role model to the organization (Hasibuan, 2010).

\section{The direct relationship of work motivation on teacher performance}

The results of the frequency distribution are known to the level of teacher motivation variables. Based on the results of the third hypothesis test, it is seen that there is a significant influence on work motivation variables. This is evidenced by several test results, such as the coefficient value of the regression results of 0.292 , which shows that a positive value increases to 0.292 when interpreted. From the result of the t-test, it is seen that the significant values of $0,000<0.05$ and 4,051 $>1,984$ indicate that there is a positive influence of work motivation on teacher performance. This means that the better the work motivation, the better the teacher's performance. And the results of the value of $\mathrm{R}^{2}$ ( $\mathrm{R}$ Square) or the coefficient of determination of $0.142(14.2 \%)$, means that the change in teacher's performance is affected by motivation. This means that the contribution of the effect of work motivation on teacher performance is $14.2 \%$, while the rest $100 \%$ -
$14.2 \%=85.8 \%$ are influenced by external variables.

A trained instructor instills some motivation in the learner by making the process enjoyable. Therefore, the students would be interested in what the teachers offer. However, if the process is spearheaded by untrained staff, there is a likelihood of it impacting negatively on learning outcomes (Suriansyah \&Aslamiah, 2018). Based on the research results from the respondents' answers, motivation is seen as a process of encouraging people to work properly by meeting their needs. When employees are aware of and responsible for their jobs, they create a stronger performance, which ultimately provides satisfying service to customers.

Based on the above description, there is a positive influence between work motivations on teacher performance. In other words, when employee motivation is high, performance increases, and vice versa. Motivation is a series of attitudes and values which influence individuals to achieve specific things following personal goals (Normianti, 2019). This attitude and value provides strength and encourages them to achieve their goal. The teacher is at the center of education and executes vital roles such as teaching guiding, directing, training, giving, assessing, and evaluating students in early childhood, primary, and secondary levels (Suriansyah \&Aslamiah, 2018). The results of this study on work motivation have a positive and significant effect on teacher performance. Therefore, the results prove that the implementation of high work motivation significantly contributes to improving teacher performance. These results indicate that the better the implementation of work motivation, the higher the performance of employees.

The findings of this study indicate that high work motivation is capable of supporting variations in change and has a significant contribution to improving teacher performance. Therefore, the teacher always has a high work motivation in carrying out the task provided by the organization. The level of work motivation possessed by the teacher is inseparable from the expected value received. With the increasingly high level of work motivation, there is an increasing impact on the completion of the tasks 
carried out by a teacher, which in turn creates high work performance. There is high work motivation on teachers of private elementary school teachers in the North Banjarbaru District, therefore, it is expected to improve employee performance. This condition is observed from the respondents' statement on the application of work motivation through indicators of the need for affiliation or social relations, as the main factor in its implementation. This means that the need for affiliation is the desire to be friends with colleagues or teachers in the organization. This fact is reflected through the willingness of teachers to work together with peers in completing assignments, making decisions, and working as a team.

\section{The direct relationship of work motivation on teacher's discipline}

Based on the results of the $4^{\text {th }}$ hypothesis test, it is seen that there is a significant influence on work motivation variables on discipline. This is evidenced by several test results, such as the value of the regression coefficient at 0.413 , which is positive by 1 point, with the teacher's discipline increasing by 0.413 points. Therefore, it is concluded that there is a positive influence between motivations on teacher discipline.

From the t-test results, the significant value of $0,000<0.05$ and $3,150>1,984$, is obtained, which indicates that there is a positive influence of work motivation on teacher discipline. This means that the better the work motivation in an organization, the higher the teacher's discipline. The value of $\mathrm{R}^{2}$ (R square) or the coefficient of determination of 0.091, means that $9.1 \%$ of changes in the variable of teacher discipline is influenced by motivation variables. This means that the contribution and influence of teachers' motivation is $9.1 \%$, while the remaining $100 \%-9.1 \%=90.9 \%$ is influenced by other variables.

Work motivation and discipline differ, though both have links in the activities of an organization. Work motivation is very important in upholding and improving the discipline of employees to achieve maximum results (Sagala, 2011). Based on the research results, the relationship between motivation and discipline is seen in motivational and hygiene factors. Based on this calculation, it is known that all aspects of motivation have a significant relationship with the variable discipline (Rahayu, 2019). The aspect of work motivation with the strongest correlation is responsibility and policies. This allows employees to increase confidence to achieve the expected goals successfully, this makes the teacher has a willingness to comply with regulations that apply in the workplace.

One other important factor that has a high effect on employee motivation is working conditions. This is because all the characteristics that exist are present in the working conditions, which tend to affect the workers' behavior to the organization. From observations made, a temporary picture was obtained, which determines motivation such as compensation systems, recognition of achievement, the relationship between subordinate superiors, employee personnel, training and development systems, work tools and equipment, leadership quality, etc. However, it seems that these characteristics have not been able to create high work motivation for teachers. Teacher unprofessionalism is both internally and externally afflicted. Their behavior, leadership, work climate, and teacher discipline are the factors contributing to them being able to abide by the professional code of conduct (Suriyansyah \& Aslamiah, 2018). Although the results of the study show that there is an influence of the climate variable on teachers' motivation, however, not all show a high level of work motivation due to changes that increase discipline and teamwork.

\section{The direct effect of work discipline on teacher performance}

Hypothesis test results showed a significant effect of discipline variables. This is evidenced by several test results, such as the value of the regression coefficient of 0.342 . This means that when work discipline increases by 1 point, teacher performance increase by 0.342 . From the results of the t-test, the significant value of $0,000<0.05$ and $7,553>1,984$, obtained a positive influence of discipline on teacher performance. This means that the higher the teacher's 
discipline at work, the better the performance results.

The facts obtained in the field support the results of this study that high work discipline can improve teacher performance based on the description of variables according to respondents' perceptions. The majority of work discipline variables were properly implemented, from indicators of compliance with applicable regulations, working hours, standards, uniforms, compliance in the use of office infrastructure (SOP). This result is also proven by the percentage of respondents' answers with the majority in the good and very good category. Therefore, the results of this study realize the enforcement of Government Regulation No. 53 of 2010 on the Discipline of Civil Servants. Performance is the result of the quality and quantity of work achieved by an employee (Mangkunegara, 2012). This performance result is influenced by the level of teacher discipline in school, as seen by several research indicators such as responsibility in completing work.

\section{The indirect relationship of transforma-} tional leadership through work discipline

The calculation of the indirect value of transformational leadership variables on teacher performance is 0.311 . This value is positive, but the indirect effect of transformational leadership on performance through discipline is smaller than the value of the direct influence of the leader on performance at 0.437 . Therefore, the work discipline which acts as a mediating variable (intervening), cannot strengthen the influence of transformational leadership on performance.

Transformational leaders tend to improve the performance of their subordinates in terms of attitude. For instance, a school's principal acts as a role model for teachers and are believed to be able to make the best decisions. Principals highly rated by teachers are tagged to possess high charisma. Transformational leadership with a charismatic personality can provide the vision and mission required by an organization (Wahjosumidjo, 2010).

Teacher performance needs to be based on a strong commitment to the school as an organization where they work. Work discipline is the willingness to obey the rules and regulations in both written and unwritten forms which are manifested in attitudes and actions to achieve set goals. Therefore, it is an awareness and willingness to comply with all applicable rules and social norms. This fact indicates that management focuses attention on work discipline as reflected by the teacher's adherence to regulations, compliance with official orders, working hours, uniform, use of office facilities, and working following rules. The courage and firmness of leaders reinforce this fact by providing strict instructions to improve teacher performance.

\section{The indirect relationship between work mo- tivation through discipline on teacher per- formance}

The calculation of the indirect effect of work motivation variables on teacher performance through disciplinary variables is 0.141 . This indicates that the value is positive, but the indirect effect of motivation on performance through discipline is smaller than the direct influence of 0.292. Therefore, work discipline is a mediating variable that is unable to strengthen the influence of motivation on teachers' performance. The respondents' results answer the questions related to the relationship with leaders and colleagues. The school was rated in a comfortable and pleasant atmosphere, which allows the stimulation of teachers to work to produce optimal performance. When the principal's attitude is caring, the teacher feels comfortable, motivated, and confident. This increases the teachers' work motivation, responsibility, achievement, self-development, and independence, thereby, leading to high performance.

The results of this study also indicate that work motivation has a positive and significant effect on teacher performance. Its measurement is following the needs of affiliation or social relations in its implementation. The results of this study interpret the need for affiliation or social relations described through the desire to be friends with colleagues or employees in the organization. Furthermore, the ability to strike a balance between attitudes and actions to realize the organizational goals of employees to work together with colleagues, superiors, and 
subordinates reflects on employee performance. Work motivation is an important determinant of an employee's performance, which supports people's behavior (Wirawan, 2017). Based on the path analysis study, the direct effect of work motivation variables on performance is greater than the performance on discipline (indirectly). This means that work motivation variables directly affect performance without discipline. Stated that one of the principles conducted by a leader is to motivate employees through recognition by giving rewards, and through praises (Suriansyah, 2015).

These efforts to motivates subordinates and offset the fulfillment of needs with recognition. It aims to motivate employees to be sincere. When teachers have high discipline in working, which is not supported by good motivation such as clarity in the distribution of authority and responsibilities, proper arrangements, compatibility, and friendly relationships with leaders or colleagues, success is eluded. Teacher performance is good when the elements consisting of teaching assignments, mastering and developing learning materials, creativity, collaboration with school members, leadership, good personality, honesty and objectivity in guiding students, and responsibility in carrying out assignments (Aslamiah, 2015). Teachers with good performance scores have an impact on the results of their activities, where the output increases in quality and quantity. Teacher performance is based on a strong commitment to the school as an organization where they work and practice their knowledge. Furthermore, their work motivation is important for sustaining a school as an educational organization. One effort to realize a strong commitment to an organization is how the principal, as a leader, conditions teachers, and other education.

\section{Conclusion and Recommendation}

Each transformational leadership, work motivation, and discipline separately have a direct positive influence on teacher performance. While transformational leadership has a direct positive effect on work discipline. Indirect relationship happens to transformational leader- ship through work discipline and works motivation through discipline on teacher performance. It is recommended for school principals to provide inspirational motivation for teachers by implementing a reward system for teachers who have good performance and for teachers to receive constructive input and criticism from the principal, and always adhere to the principal's instructions for the progress of students.

It is also recommended that analyze research on teacher performance in more depth by using other variables, such as job satisfaction, organizational culture, and training which are thought to also affect performance. Research can also be done with qualitative methods with the theme of performance and work environment that allows to find data and new facts about the work environment and performance that has been practiced by a school.

\section{Acknowledgment}

Our gratitude and appreciation extend to my advisors, my friends, etc involved and contributed to completing this research.

\section{References}

Aslamiah. (2015). Hubungan kepemimpinan transformasional kepala sekolah, kepuasan kerja, komitmen organisai, dan organizational citizenship behavior (OCB) dengan kinerja guru sekolah dasar negeri di kota Banjarmasin. (Doctoral dissertation) Program Studi Manajemen Pendidikan Pascasarjana Universitas Negeri Malang.

Bubu. (2016). Hubungan Kepemimpinan Transformasional dan Disiplin Kerja Dengan Kinerja Guru Sekolah Dasar Di Kecamatan Selat Kabupaten Kapuas. Tesis. Banjarmasin: Program Pascasarjana Universitas Lambung Mangkurat.

Hasibuan, M. (2010). Manajemen sumber daya manusia. Jakarta: PT Bumi Aksara.

Mangkunegara, A. (2012). Manajemen sumber daya manusia perusahaan. Bandung: PT Remaja Rosda Karya Offset.

Normianti, H. (2019). Hubungan kepemimpinan transformasional kepala sekolah, motivasi kerja guru, komitmen organiasasi dengan kinerja guru sdn se-kecamatan labuan amas selatan. Journal of K6, Education, and Managemen, 2(1), 1-5.

Prijodarminto, S. (2014). Disiplin: kiat menuju sukses. Jakarta: Pradnya Paramita.

Rahayu. (2019). Pengaruh gaya kepemimpinan dan iklim kerja terhadap disiplin kerja dengan intervening semangat kerja 
pada guru sman di wilayah kota tabalong. International Journal of Scientific Development and Research (IJSDR),4(1),142.

Rasyidah. (2019). Pengaruh kepemimpinan, iklim kerja dan motivasi terhadap kinerja guru sekolah dasar negeri di kecamatan Banjarmasin utara. International Journal of Scientific Development and Research (IJSDR), 4 (1), 142.

Sagala. (2011). Kemampuan profesional guru dan tenaga kependidikan. Bandung: Alfabeta.

Sundari. (2019). Pengaruh kepemimpinan, iklim kerja dan semangat kerja terhadap disiplin guru sekolah dasar di kecamatan batu ampar kabupaten tanah laut. Journal of K6, Education, and Management, 2(1), 142.

Supardi. (2014). Kinerja Guru. Jakarta: Raja Grafindo Persada.

Supriyadi. (2002). Mengangkat Citra dan Martabat Guru. Yogyakarta: Adicita Karya Nusa.

Suriansyah, A. (2015). Profesi kependidikan perfektif guru profesional. Jakarta: PT. Raja Grafindo Persada.
Suriansyah, A., \& Aslamiah. (2018). Strategi kepemimpinan kepala sekolah, guru, orang tua, dan masyarakat dalam membentuk karakter siswa._(Unpublished master's thesis). Universitas Lambung Mangkurat, Banjarmasin, Indonesia. Suriansyah, A. (2018). Contribution on supervision of supervisor, principals motivation, kindergarten teacher performanceto improving the kindergarten quality in west Banjarmasin, Indonesia. (Unpublished master's thesis). Lambung Mangkurat University.

Usman, H. (2011). Manajemen : teori, praktik, dan riset pendidikan. Jakarta: Bumi Aksara.

Wahjosumidjo. (2010). Kepemimpinan kepala sekolah, tinjauan teoritik dan. permasalahannya. Jakarta: PT. Raja Grafindo Persada.

Wirawan. (2017). Evaluasi kinerja sumber daya manusia: teori, praktik, dan penelitian. Jakarta: Salemba Empat. 